\title{
Dietary overlap among native and non-native fish in Patagonian low-order streams
}

\author{
Cecilia Yanina Di Prinzio ${ }^{1,2 *}$ and Ricardo Jorge Casaux ${ }^{1,2,3}$ \\ ${ }^{1}$ Consejo Nacional de Investigaciones Científicas y Técnicas (CONICET), Av. Rivadavia 1917, (1033) Buenos Aires, Argentina \\ ${ }^{2}$ Laboratorio de Investigaciones en Ecología y Sistemática Animal (LIESA), Universidad Nacional de la Patagonia, Ruta 259 km. 5 , \\ Planta de Aromáticas, 9200 Esquel, Chubut, Argentina \\ 3 Instituto Antártico Argentino, Cerrito 1248, (1010) Buenos Aires, Argentina
}

Received 13 December 2010; Accepted 28 July 2011

\begin{abstract}
The diet composition and feeding strategy of native and exotic fish species were studied from May 2005 to February 2006 in three Patagonian low-order streams. A total of 464 fish were caught, which belonged to the exotic species Oncorhynchus mykiss (270), Salmo trutta (177) and the native species Hatcheria macraei (17). The analysis of 336 stomach contents indicated that at the individual level, the three species had a generalized feeding strategy based on benthic invertebrates (Plecoptera, Trichoptera, Coleoptera and Diptera). In the three streams, the widest population niches were observed in winter. There was, however, also a slight tendency toward an increased between-phenotype contribution to the niche width in same season, indicating that a small proportion of individuals within the fish populations specialized by predominantly feeding on a few specific prey species. Hence, the wide population niche widths observed throughout the year were partly a result of mixed individual feeding strategies within the populations. The higher diet overlaps were registered between exotics $O$. mykiss-S. trutta at Glyn and Carbón, and $O$. mykiss and the native H. macraei at Manguera, but it changed markedly through the year, perhaps depending on temporal changes in food availability suggesting a competitive coexistence of these species. This is mainly related to the fact that both species changed their food preferences in spring and foraged almost exclusively on Aubertoperla illiesi. This implies that in order to reduce the predation risk or the inter-specific competition for food, the fish species might partition the feeding habitats.
\end{abstract}

Key words: Hatcheria macraei / salmonids / feeding strategies / Patagonia / Argentina

\section{Introduction}

The introduction of non-indigenous fish is considered one of the most important anthropogenic impacts on freshwater ecosystems (Kolar and Lodge, 2000). Fishes of the Salmonidae family have been widely introduced in the Southern Hemisphere and their ecological impacts have been substantial (Townsend, 2003). To understand the magnitude and implications of such impacts multi-species approaches are required.

In the last century Patagonia was affected by a continuous salmonid species stocking (Pascual et al., 2007). Thirteen salmonid species were introduced in the Argentinean Patagonia and among them the most widely distributed are Oncorhynchus mykiss, Salmo trutta and Salvelinus fontinalis. Recently, the anadromous

\footnotetext{
*Corresponding author: cydiprinzio@yahoo.com.ar
}

Chinook salmon Oncorhynchus tshawytscha was observed spawning in headwaters of Pacific and Atlantic basins in Argentina (Pascual and Ciancio, 2007; Soto et al., 2007; Di Prinzio and Pascual, 2008). There is evidence indicating that the exotic $O$. mykiss feed intensively on native fishes (McDowall, 2003; Arismendi et al., 2009; among others).

The native fish species are widespread, being distributed throughout most of the region's high-order rivers (Pascual et al., 2007). Their status in low-order streams is, however, poorly understood. In consequence, the understanding of the role of fish in freshwater ecosystems is important given that when species with similar feeding behaviors co-occur and the resource availability is limited in quantity or diversity some degree of food competition might be expected (Odum, 1971). In that situation, different feeding strategies may help to reduce interspecific competition. Thus, under some circumstances, competition may become an important force 


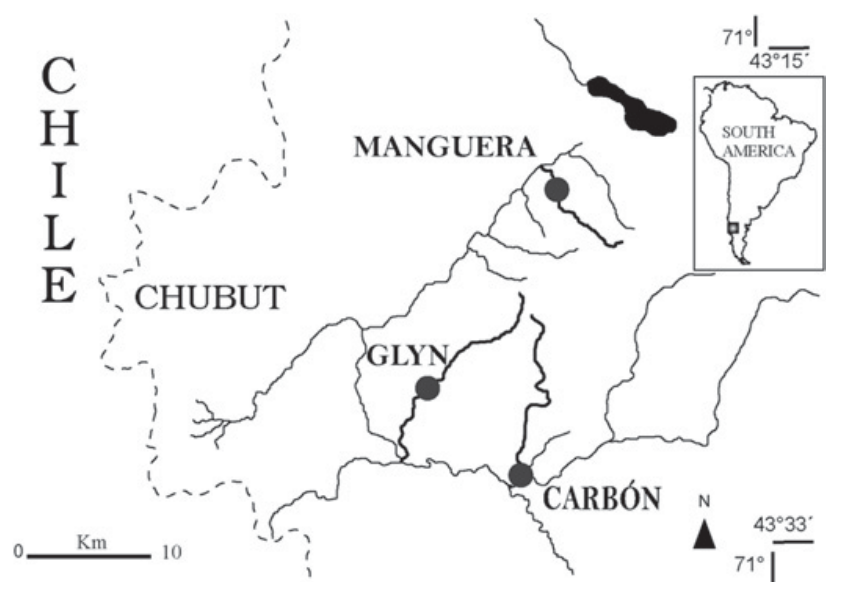

Fig. 1. Location of the three sampled streams at Northwest Chubut, Patagonia, Argentina.

determining the feeding behavior and diet composition of predators.

Vitousek (1990) mentioned that in freshwater systems, predators frequently forage selectively on certain prey types, whereas Townsend (2003) suggested that predation has important effects at individual, population, community and ecosystem levels. Thus, predation represents a strong selective force that shapes and determines the structure of populations at lower trophic levels (Peckarsky, 1982; Bechara et al., 1992), and can alter the abundance and composition of the prey community (Dahl and Greenberg, 1996). Moreover, if the interactions are of great magnitude, predators can also alter the abundance of resources at lower trophic levels indirectly via "trophic cascade" by reducing consumer abundance and the consumer's consumption of resources (Brönmark et al., 1997).

There have been few studies focusing on the predatorprey interactions in Patagonia (Buria et al., 2007; Aigo et al., 2008; Molineri, 2008) and only some of them considered the dietary overlap between native and exotic species (Ferriz, 1994; Barros et al., 2001; Lattuca et al., 2007). Thus, the main objective of this study is to describe the diet composition of freshwater fish at three Patagonian low-order streams. As secondary objectives we will estimate the dietary overlap and the potential resource competition among native and exotic species.

\section{Material and methods}

\section{Study area}

The study was conducted in three streams located in northwest Patagonia (Glyn $43^{\circ} 27^{\prime} \mathrm{S}, 71^{\circ} 33^{\prime} \mathrm{W}$; Manguera $43^{\circ} 33^{\prime} \mathrm{S}, 71^{\circ} 26^{\prime} \mathrm{W}$ and Carbón $43^{\circ} 32^{\prime} \mathrm{S}, 71^{\circ} 28^{\prime} \mathrm{W}$ ) in the Andean-Humid and the Sub-Andean Sub-humid biozones (Fig. 1). The landscape is strongly influence by glacial action and strong fluvial erosion. River discharge is bimodal and determined by rainfall, which occurs mainly in winter and by the snowmelt in spring (Coronato and del Valle, 1988). The streams under study are second (Glyn) or third (Manguera and Carbón) order and belong to the Carrenleufú basin. The streams are $15 \mathrm{~km}$ (Manguera), $25 \mathrm{~km}$ (Glyn) and $30 \mathrm{~km}$ (Carbón) long. Catchments are surrounded by sub-Antartic forest characterized by perennial (Austrocedrus chilensis, Nothofagus dombeyi and Maytenus boaria) and deciduous (Nothofagus pumilio and Nothofagus antarctica) species.

\section{Measurement of physical and chemical variables}

Samples were obtained in May (autumn), September (winter) and December (spring) 2005 and in February 2006 (summer). In each sampled site, flow velocity, water depth, dry widths of channel, water discharge, water temperature, conductivity, $\mathrm{pH}$, dissolved oxygen, turbidity, total suspended solids, soluble reactive phosphate, nitrate plus nitrite nitrogen and ammonia were calculated to determine whether environmental conditions were similar between rivers and stable. Statistical comparisons of values obtained for physical and chemical variables at each site were conducted by applying the Kruskal-Wallis test (Sokal and Rohlf, 1995).

\section{Fish sampling}

Fish were sampled seasonally, in May (autumn), September (winter) and December (spring) 2005 and in February 2006 (summer) using a portable backpack electrofishing gear (Coffelt Mark-10 CPS, output $350 \mathrm{~V}$ ) along reaches of $100 \mathrm{~m}$ long. The width of the sampling area was coincident with the stream width, except for those sections presenting non-wadeable sites with swift currents (Carbón stream). The sampled area was estimated considering the reach length and width. The fish sampled were identified to species, counted, measured in total length $(\mathrm{cm})$ and weighted (g). The sampling area was estimated considering the length and width of the reach. Thus, for each stream the density and biomass were estimated and expressed as the number of individuals (individuals. $\mathrm{m}^{-2}$ ) and biomass $\left(\right.$ g. $\left.\mathrm{m}^{-2}\right)$ per area sampled, respectively. The development of a sampling program may affect the fish populations under study (Casaux and Barrera-Oro, 2002), thus only up to 30 individuals (selected randomly) per species were freezed in the field at $-10{ }^{\circ} \mathrm{C}$ and at the laboratory were dissected for diet analysis.

\section{Dietary analyses}

Fish were dissected and the stomachs were separated for diet analysis. The stomach fullness was assessed using a five-point scale method employing a percentage scale ranging from empty $(0 \%)$ to full $(100 \%)$ (Amundsen et al., 1996). Food items were removed and identified to the lowest taxonomic level possible. The composition of the diet was calculated in terms of percent abundance $\left(A_{i}\right)$, 
frequency of occurrence $\left(F_{i}\right)$ and prey-specific abundance $\left(P_{i}\right)$ following Amundsen et al. (1996):

$$
\begin{gathered}
A_{i}=\left(\sum S_{i} / \sum S_{t}\right) \times 100 \\
F_{i}=N_{i} / N \\
P_{i}=\left(\sum S_{i} / \sum S t_{i}\right) \times 100
\end{gathered}
$$

where $S_{i}$ is the contribution of prey $i$ to stomach fullness, $S t_{i}$ is the total stomach fullness of fish with prey $i$ in their stomach and $S_{t}$ is the total stomach fullness of the fish, $N_{i}$ is the number of fish with prey $i$ in their stomach and $N$ is the total number of fish with stomach contents. index:

The diet width $(B)$ was calculated using Levins (1968)

$$
B=1 / \sum p_{i}^{2}
$$

where $p_{i}$ is the proportion of each prey type $i$ in the diet and equals $A_{i}$ expressed as fraction rather than percentage.

\section{Diet overlap}

Dietary overlap between the fish species was calculated as an index expressed as a percentage overlap (Krebs, 1989):

$$
P_{j k}=\left[\sum_{1}^{n} \operatorname{minimum} P_{i j}, P_{i k}\right] \times 100
$$

where $P_{i k}$ is the percentage overlap between species $j$ and species $k, P_{i k}$ are the proportions of resource $i$ in relation to the total resources used by species $j$ and $k$, respectively, and $n$ is the total number of prey categories. The overlap is considered to be significant when the index value exceeds 60\% (Wallace, 1981).

\section{Feeding strategy and phenotype contributions to the niche width}

Food-niche characteristics were analyzed by the graphical method of Amundsen et al. (1996). For each prey type, the prey-specific abundance $\left(P_{i}\right)$ is plotted against the frequency of occurrence $\left(F_{i}\right)$ on a two-dimensional graph. Prey importance, feeding strategy and phenotype contribution to the niche width can be interpreted along the diagonals and axes of the diagram (see Amundsen et al., 1996). The diagonal from the lower left to the upper right corner provides a measure of prey importance for the whole population with dominant prey at the upper, right corner and rate and unimportant prey at the lower end. The vertical axis represents the feeding strategy in terms of specialization or generalization: specialists have prey points positioned in the upper part of the graph, whereas generalists have all prey points in the lower part. Points located in the upper left indicate specialization by subgroups of the predator population, whereas points in the upper right indicate specialization by the whole predator population on given prey. Hence, if one or a few points are located in the upper right, this reflects a predator population with a narrow niche width. When there are no prey points in this part of the diagram this reflects a predator population with a broader niche width. Prey points in the upper left and lower right corner represent the same percent abundance in the diet of the population as a whole, but illustrate totally different feeding strategies among the individual predators. Prey with high specific abundance and low occurrence (upper left) have been consumed by a few individuals displaying specialization, whereas prey with a low specific abundance and a high occurrence (lower right) have been eaten occasionally by most individuals. These differences are related to the between- and within-phenotype contributions to niche width, respectively. Points in the upper right part of the graph (i.e., above the diagonal from lower left to upper right) reflect a population with a high betweenphenotype component (high BPC) with individuals specializing on different prey categories. Points in the opposite part (below the diagonal from lower left to upper right) represent a high within-phenotype component (high WPC) and the individuals utilize many common preys none of which dominate the diet (Roughgarden, 1972; Amundsen, 1995). In practical terms, a high WPC occurs when all prey categories have been eaten by most predators, but in small proportions, whereas a high BPC occurs when each prey category has been subjected to specialization, but only by a small fraction of the predator population.

\section{Results}

\section{Environmental features}

Sites were located between $403 \mathrm{~m}$. a.s.l. (Carbón) and 699 m.a.s.l. (Manguera) (Table 1). Flow velocity was comprised between $0.8 \mathrm{~m} . \mathrm{s}^{-1}$ (Carbón) and $1.1 \mathrm{~m} . \mathrm{s}^{-1}$ (Glyn). The streambed wet width ranged from 4.2 to $18.8 \mathrm{~m}$ in Glyn and Carbón, respectively. The lowest dissolved oxygen content was observed at Carbón $\left(11.9 \mathrm{mg} \cdot \mathrm{L}^{-1}\right)$ and the highest one at Glyn $\left(12.4 \mathrm{mg} . \mathrm{L}^{-1}\right)$. Carbón stream presented the highest conductivity $\left(70.3 \mu \mathrm{S}_{20} . \mathrm{cm}^{-1}\right)$, whereas the highest concentrations of soluble reactive phosphate $\left(0.8 \mu \mathrm{g} . \mathrm{L}^{-1}\right)$ and total suspended solid (5.1 mg. $\mathrm{L}^{-1}$ ) were registered at Manguera stream. Wet width and mean discharge was significantly higher (Kruskal-Wallis, $P<0.05$ ) in Carbón stream than in the remaining sites.

\section{Fish analysis}

A total of 464 fish was caught and the individuals belonging to exotic species (O. mykiss and S. trutta) largely 
Table 1. Locations of the three sampled streams and environmental features during the study period $(n=4)$. Values are presented as mean values $( \pm \mathrm{SD})$.

\begin{tabular}{|c|c|c|c|}
\hline & Glyn & Manguera & Carbón \\
\hline$\overline{\text { Latitude (S) }}$ & $43^{\circ} 27^{\prime} 33.7^{\prime \prime}$ & $43^{\circ} 33^{\prime} 25^{\prime \prime}$ & $43^{\circ} 32^{\prime} 12.5^{\prime \prime}$ \\
\hline Longitude (W) & $71^{\circ} 33^{\prime} 25^{\prime \prime}$ & $71^{\circ} 26^{\prime} 35.1^{\prime \prime}$ & $71^{\circ} 28^{\prime} 20.3^{\prime \prime}$ \\
\hline Altitude (m a.s.l) & 615 & 699 & 403 \\
\hline Stream order & 2 & 3 & 3 \\
\hline Wet width (m) & $4.2 \pm 0.8$ & $5.8 \pm 0.7$ & $18.8 \pm 3.7^{*}$ \\
\hline Depth (m) & $0.2 \pm 0.1$ & $0.2 \pm 0.0$ & $0.3 \pm 0.1$ \\
\hline Water temperature $\left({ }^{\circ} \mathrm{C}\right)$ & $7.4 \pm 2.2$ & $7.1 \pm 1.4$ & $8.1 \pm 2.1$ \\
\hline Flow velocity $\left(\mathrm{m} . \mathrm{s}^{-1}\right)$ & $1.1 \pm 0.5$ & $0.9 \pm 0.4$ & $0.8 \pm 0.2$ \\
\hline Discharge $\left(\mathrm{m} \cdot \mathrm{seg}^{-3}\right)$ & $1.1 \pm 1.1$ & $1.0 \pm 0.8$ & $4.8 \pm 2.9^{*}$ \\
\hline $\mathrm{pH}$ & $7.2 \pm 0.1$ & $7.4 \pm 0.4$ & $7.2 \pm 0.2$ \\
\hline Dissolved oxygen (mg. $\mathrm{L}^{-1}$ ) & $12.4 \pm 3.7$ & $12.3 \pm 2.0$ & $11.9 \pm 3.6$ \\
\hline Conductivity $\left(\mu \mathrm{S}_{20} \cdot \mathrm{cm}^{-1}\right)$ & $56.8 \pm 15.8$ & $65.0 \pm 21.6$ & $70.3 \pm 18.4$ \\
\hline Turbidity (NTU) & $10.3 \pm 17.9$ & $8.5 \pm 12.4$ & $7.0 \pm 6.8$ \\
\hline Ammonia $\left(\mu \mathrm{g} . \mathrm{L}^{-1}\right)$ & $0.9 \pm 0.8$ & $1.0 \pm 0.8$ & $1.0 \pm 0.7$ \\
\hline Nitrate + nitrate nitrogen $\left(\mu \mathrm{g} . \mathrm{L}^{-1}\right)$ & $0.3 \pm 0.2$ & $0.2 \pm 0.3$ & $0.3 \pm 0.2$ \\
\hline Soluble reactive phosphate $\left(\mu \mathrm{g} . \mathrm{L}^{-1}\right)$ & $0.4 \pm 0.2$ & $0.8 \pm 0.6$ & $0.5 \pm 0.1$ \\
\hline Total suspended solids (mg.L ${ }^{-1}$ ) & $1.1 \pm 0.6$ & $5.1 \pm 7.3$ & $2.6 \pm 1.31$ \\
\hline
\end{tabular}

*Indicates significant differences between values (Kruskal-Wallis test, $P<0.05$ ).

Table 2. Fish abundance, in terms of density (ind. $\mathrm{m}^{-2}$ ) and biomass $\left(\mathrm{g} \cdot \mathrm{m}^{-2}\right.$ ), at the three sampled sites at Northwest Patagonia, Argentina. - indicates no captures.

\begin{tabular}{|c|c|c|c|c|c|c|c|}
\hline & \multirow[b]{2}{*}{ Specie } & \multicolumn{2}{|c|}{ Glyn } & \multicolumn{2}{|c|}{ Manguera } & \multicolumn{2}{|c|}{ Carbón } \\
\hline & & (ind. $^{-2}$ ) & $\left(\mathrm{g} \cdot \mathrm{m}^{-2}\right)$ & (ind. $\mathrm{m}^{-2}$ ) & $\left(\mathrm{g} \cdot \mathrm{m}^{-2}\right)$ & (ind.m ${ }^{-2}$ ) & $\left(\mathrm{g} \cdot \mathrm{m}^{-2}\right)$ \\
\hline \multirow[t]{4}{*}{$\overline{\text { Autumn }}$} & O. mykiss & 0.19 & 4.40 & 0.17 & 1.95 & 0.16 & 2.33 \\
\hline & S. trutta & 0.18 & 1.84 & - & - & 0.10 & 2.28 \\
\hline & H. macraei & 0.00 & & 0.02 & 0.05 & - & - \\
\hline & Total & 0.37 & 6.24 & 0.19 & 2.01 & 0.26 & 4.61 \\
\hline \multirow{4}{*}{ Winter } & O. mykiss & 0.13 & 0.20 & 0.03 & 0.42 & 0.23 & 3.35 \\
\hline & S. trutta & 0.17 & 0.64 & & & 0.11 & 0.99 \\
\hline & H. macraei & 0.00 & & 0.01 & 0.04 & & \\
\hline & Total & 0.30 & 0.84 & 0.04 & 0.45 & 0.34 & 4.34 \\
\hline \multirow[t]{4}{*}{ Spring } & O. mykiss & 0.04 & 0.87 & 0.01 & 0.09 & 0.07 & 0.63 \\
\hline & S. trutta & 0.09 & 3.15 & - & - & 0.09 & 2.03 \\
\hline & H. macraei & 0.01 & 0.12 & 0.006 & 0.03 & - & - \\
\hline & Total & 0.15 & 4.15 & 0.02 & 0.12 & 0.16 & 2.66 \\
\hline \multirow[t]{4}{*}{ Summer } & O. mykiss & 0.38 & 4.26 & 0.06 & 1.29 & 0.28 & 3.62 \\
\hline & S. trutta & 0.30 & 3.03 & - & - & 0.30 & 2.57 \\
\hline & H. macraei & 0.01 & 0.02 & 0.01 & 0.06 & - & - \\
\hline & Total & 0.69 & 7.31 & 0.07 & 1.36 & 0.58 & 6.19 \\
\hline \multirow{3}{*}{$\begin{array}{c}\text { Annually } \\
\text { (mean) }\end{array}$} & O. mykiss & $0.19 \pm 0.14$ & $2.43 \pm 2.21$ & $0.07 \pm 0.07$ & $0.94 \pm 0.85$ & $0.18 \pm 0.09$ & $2.48 \pm 1.35$ \\
\hline & S. trutta & $0.19 \pm 0.09$ & $2.17 \pm 1.18$ & - & - & $0.15 \pm 0.10$ & $1.96 \pm 0.69$ \\
\hline & H. macraei & $0.01 \pm 0.01$ & $0.07 \pm 0.07$ & $0.01 \pm 0.00$ & $0.05 \pm 0.02$ & - & - \\
\hline
\end{tabular}

predominate samples $(96.34 \%)$. O. mykiss was the most abundant fish (270 individuals, 0.44 ind. $\mathrm{m}^{-2}$ ), followed by $S$. trutta (177 individuals, 0.34 ind. $\mathrm{m}^{-2}$ ) and Hatcheria macraei (17 individuals, 0.02 ind. $\mathrm{m}^{-2}$ ) (Table 2). A similar pattern was observed in the contribution of the different species to the samples by biomass: O. mykiss $5.85 \mathrm{~g} . \mathrm{m}^{-2}$, S. trutta $4.13 \mathrm{~g} . \mathrm{m}^{-2}$ and $H$. macraei $0.12 \mathrm{~g} . \mathrm{m}^{-2}$. The size of the fish caught ranged between 3.0 ( $H$. macraei at Manguera) and $27.0 \mathrm{~cm}$ ( $S$. trutta at Carbón), whereas their weight ranged between 0.1 ( $H$. macraei at Manguera) and 378.8 (O. mykiss at Glyn) g (see details in Table 3).

\section{Dietary analyses}

The diet composition of the three fish species (336 stomachs) was diverse and benthic organisms largely dominated in the samples. A total of 88 prey taxa were identified from the stomach contents (Fig. 2). Depending on the season and site, the most important prey species of O. mykiss were Aubertoperla illiesi, Antactoperla michaelseni, Nousia delicata, Smicridea annulicornis, Parasericostoma ovale, Simuliidae larvaes and vegetable fragments. Similarly, A. michaelseni, Limnoperla jaffueli, N. delicata, A. illiesi, S. annulicornis and Athericidae 


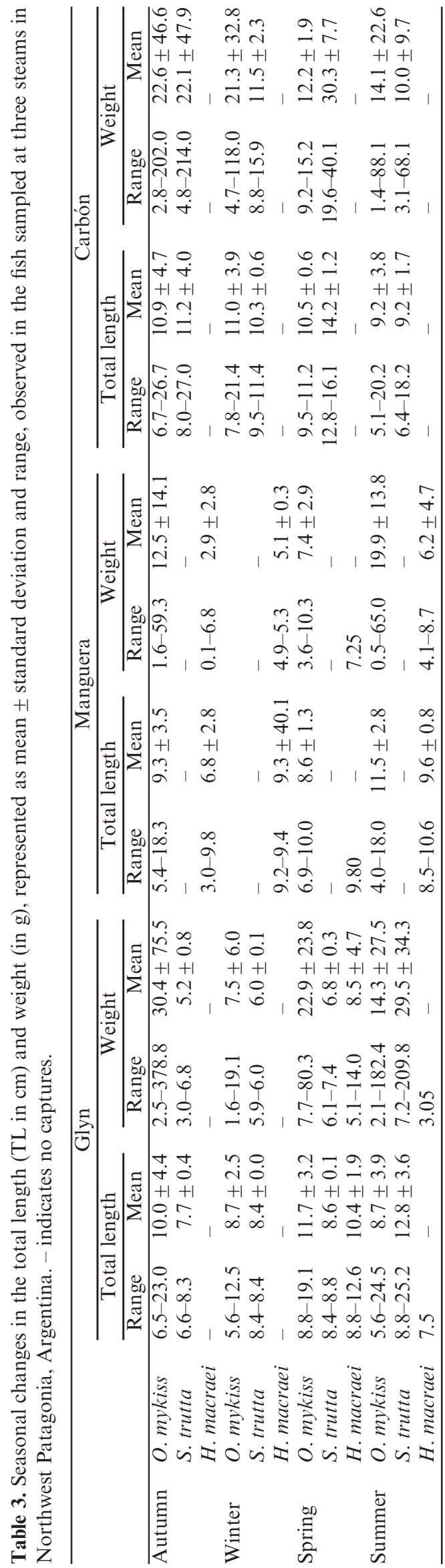

larvaes were the most important preys in the diet of S. trutta. Hatcheria macraei foraged predominantly on A. illiesi, A. michaelseni, Simuliidae larvaes, Paratrichocladius sp. and stones. The differences in the yearly composition of the diet between $O$. mykiss and $S$. trutta at Glyn $\left(\chi_{47}^{2}=206.61 ; P<0.05\right)$ and Carbón $\left(\chi_{47}^{2}=288.17\right.$; $P<0.05)$ were statistically significant. Likewise, the composition of the diet of $O$. mykiss and $H$. macraei at Manguera differed statistically $\left(\chi_{42}^{2}=400.00 ; P<0.05\right)$.

The total number and weight of prey and the species richness observed in the stomach contents did not vary significantly according to site and season (Kruskal-Wallis, $P=$ n.s.), but differed among fish species (Kruskal-Wallis, $P<0.05)$. Thus, the total number and weight of prey and the species richness observed in the stomach contents of $H$. macraei were significantly lower than in the salmonid species.

\section{Diet overlap}

Overall, only minor dietary overlap was observed in winter between all three species (Table 4). The dietary overlap observed between the introduced $O$. mykiss and $S$. trutta at Glyn exceeded $60 \%$ in autumn, spring and summer (Table 4). The dietary overlap between $O$. mykiss and $H$. macraei at Manguera exceeded $60 \%$ only in spring (Table 4). The dietary overlap between O. mykiss and $S$. trutta exceeded $60 \%$ only in autumn, but in spring such value approached significance (Table 4).

\section{Feeding strategy and phenotype contributions to the niche width}

The maximum value of diet-width index varied with the season and site. Thus, at Glyn O. mykiss showed the maximum value of this index in autumn, while in $S$. trutta this occurred in winter. At Manguera, the maximum value of diet-width index of $O$. mykiss and H. macraei occurred in spring and autumn respectively. At Carbón the maximum value of diet-width index of O. mykiss was in spring, whereas in S. trutta was in autumn (Table 5).

Most of the prey types had very similar contributions to the diet of the three fish species both in terms of frequency of occurrence and prey-specific abundance (Fig. 3), and the three fish species exhibited a remarkable similarity in their feeding strategies and prey utilization patterns. At the individual level, there was a clear generalized feeding strategy within the three species as the prey points were mainly located in the lower half of the diagram and the prey-specific abundance only occasionally exceeded 50\% (Fig. 3(A, E, G, H, I, L)). The prey species that showed high specific abundance and low occurrence (upper left) have been consumed by a few individuals displaying specialization were Lymnaea sp. for S. trutta and Limnephilidae for O. mykiss in Glyn (autumn) (Fig. 3(A)). In the same way, in Manguera the 


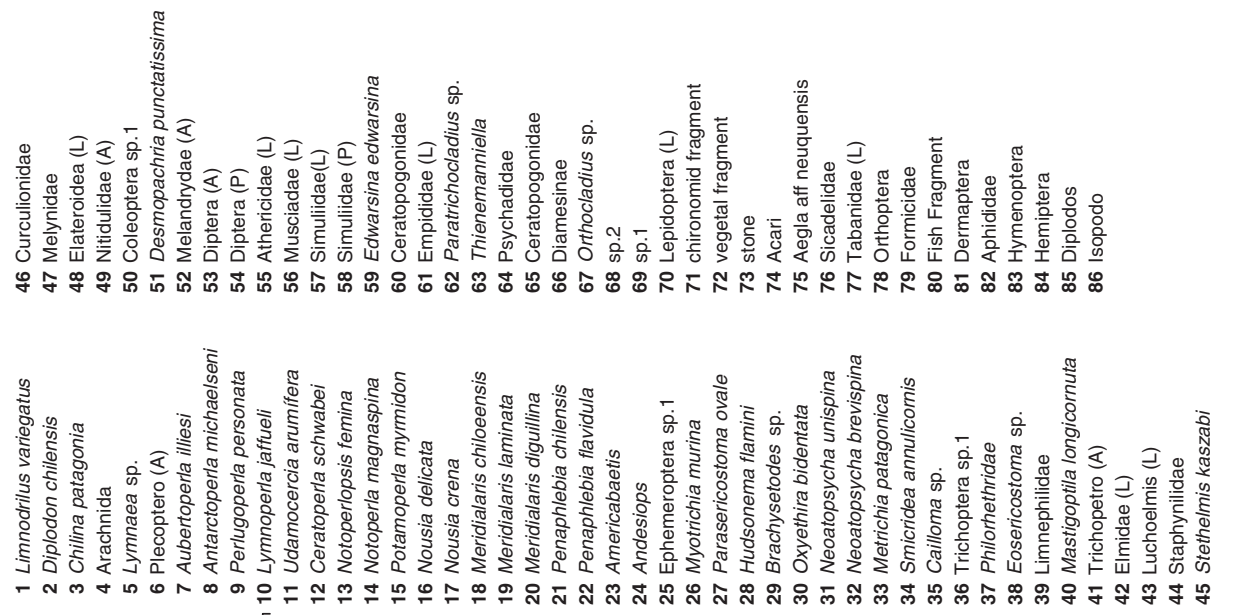

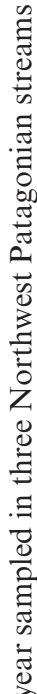

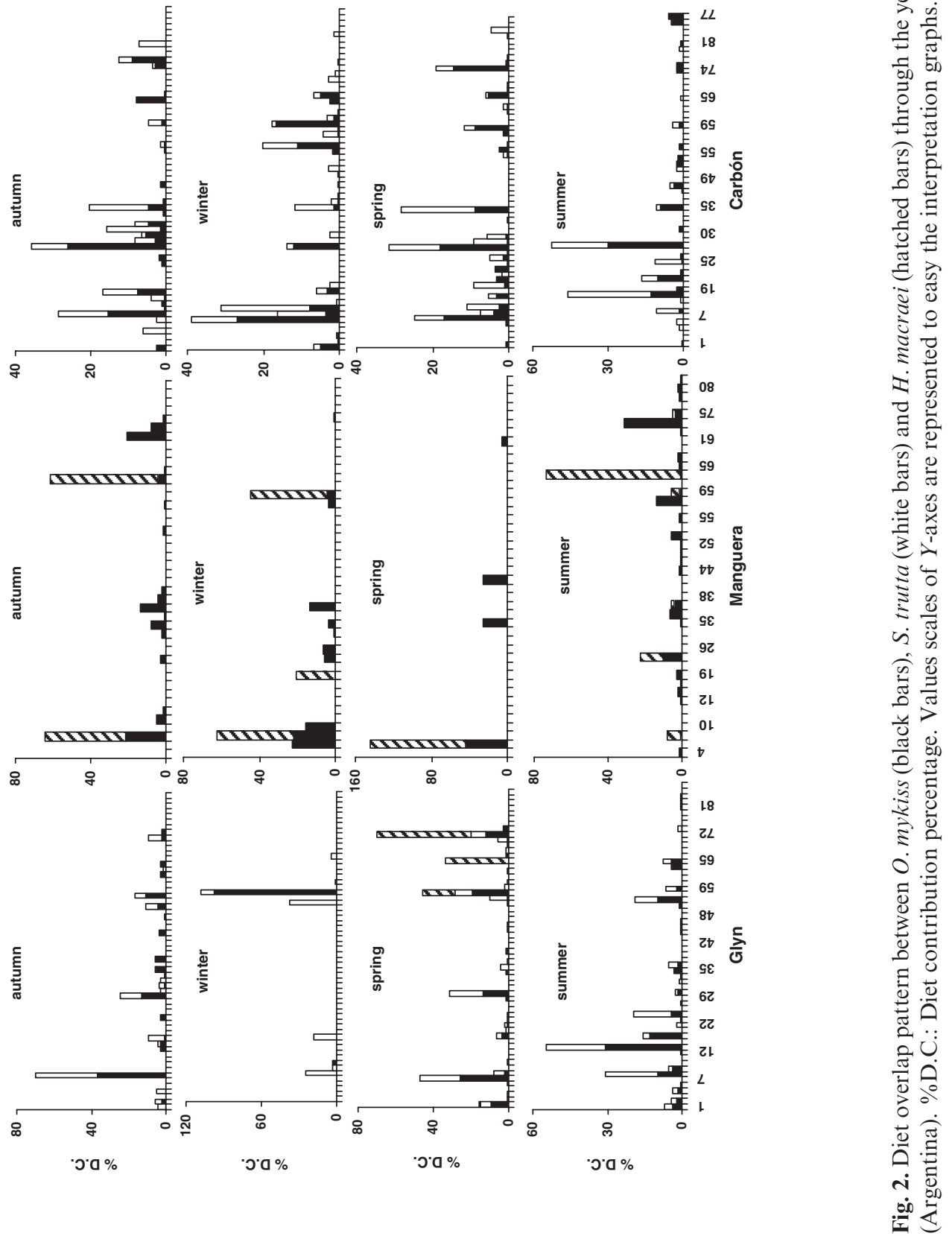


prey species that showed high specific abundance and low occurrence for O. mykiss were Mastigoptila longicornuta (autumn), Metrichia patagonica and S. annulicornis

Table 4. Prey overlap (\%) among fish represented in three streams located in Northwest Patagonia Argentina. - indicates no captures.

\begin{tabular}{|c|c|c|c|c|}
\hline & & Glyn & Manguera & Carbon \\
\hline \multirow[t]{2}{*}{ Autumn } & O. mykiss-S. trutta & 61.16 & - & 60.96 \\
\hline & O. mykiss-H. macraei & - & 15.73 & - \\
\hline \multirow[t]{2}{*}{ Winter } & O. mykiss-S. trutta & 30.55 & - & 43.74 \\
\hline & O. mykiss-H. macraei & - & 29.03 & - \\
\hline \multirow[t]{3}{*}{ Spring } & O. mykiss-S. trutta & 73.39 & - & 57.23 \\
\hline & O. mykiss-H. macraei & 1.24 & 62.50 & - \\
\hline & S. trutta-H. macraei & 2.85 & - & - \\
\hline \multirow[t]{2}{*}{ Summer } & O. mykiss-S. trutta & 62.89 & - & 46.81 \\
\hline & O. mykiss-H. macraei & - & 14.74 & - \\
\hline
\end{tabular}

Table 5. Population niche width (Levins index, B) of the three species presented in the three streams studied in the Northwest Patagonia, Argentina. - indicates no captures.

\begin{tabular}{llcccc}
\hline & & Autumn & Winter & Spring & Summer \\
\hline Glyn & O. mykiss & 0.27 & 0.06 & 0.22 & 0.24 \\
& S. trutta & 0.29 & 0.50 & 0.22 & 0.26 \\
& H. macraei & - & - & - & - \\
Manguera & O. mykiss & 0.30 & 0.45 & 0.71 & 0.22 \\
& H. macraei & 0.96 & - & - & 0.16 \\
Carbon & O. mykiss & 0.31 & 0.23 & 0.32 & 0.31 \\
& S. trutta & 0.61 & 0.34 & 0.43 & 0.27 \\
\hline
\end{tabular}

(spring) and Coleoptera sp.1 (summer), while for H. macraei was Paratrichocladius sp. (autumn and summer) and A. illiesi in spring (Fig. 3(E, G, H)). In Carbón, Dermaptera and Oxyethira bidentata were the most consumed prey in autumn by S. trutta (Fig. 3(I)) and Aegla aff neuquensis for O. mykiss (summer) (Fig. 3(L)).

At the population level, both $H$. macraei (Manguera) and O. mykiss (Glyn) showed two different feeding strategies by specialization in spring, summer (Fig. 3(G, H)) and winter (Fig. 3(B)), respectively and a generalization at the rest of the year. The population specialization of the two species was exposed by one prey point being located toward upper right of the diagram. In contrast, no prey types emerged as particularly important in the diet of these species and all prey points were located along or below the diagonal from the upper left to the lower right corner (Fig. 3(E, F, A, C, D)). In spring, the population specialization of $H$. macraei was directed toward the Plecoptera $A$. illiesi, whereas in summer with the Diptera Paratrichocladius. The population specialization in O. mykiss was related to the Diptera Simuliidae larvae. Thus, a large number of prey types were utilized, but all had a low contribution to the diet, resulting in pronounced population generalizations and large niche widths of both species during the rest of the year (Table 5).

Overall, in the three streams, the wider population niches observed was in winter (Fig. 3(B, F, J)), spring (Glyn and Carbón) (Fig. 3(C, J)) and summer (Glyn) (Fig. 3(D)). This is illustrated in the diagram by most of the prey points being located to the lower right of the
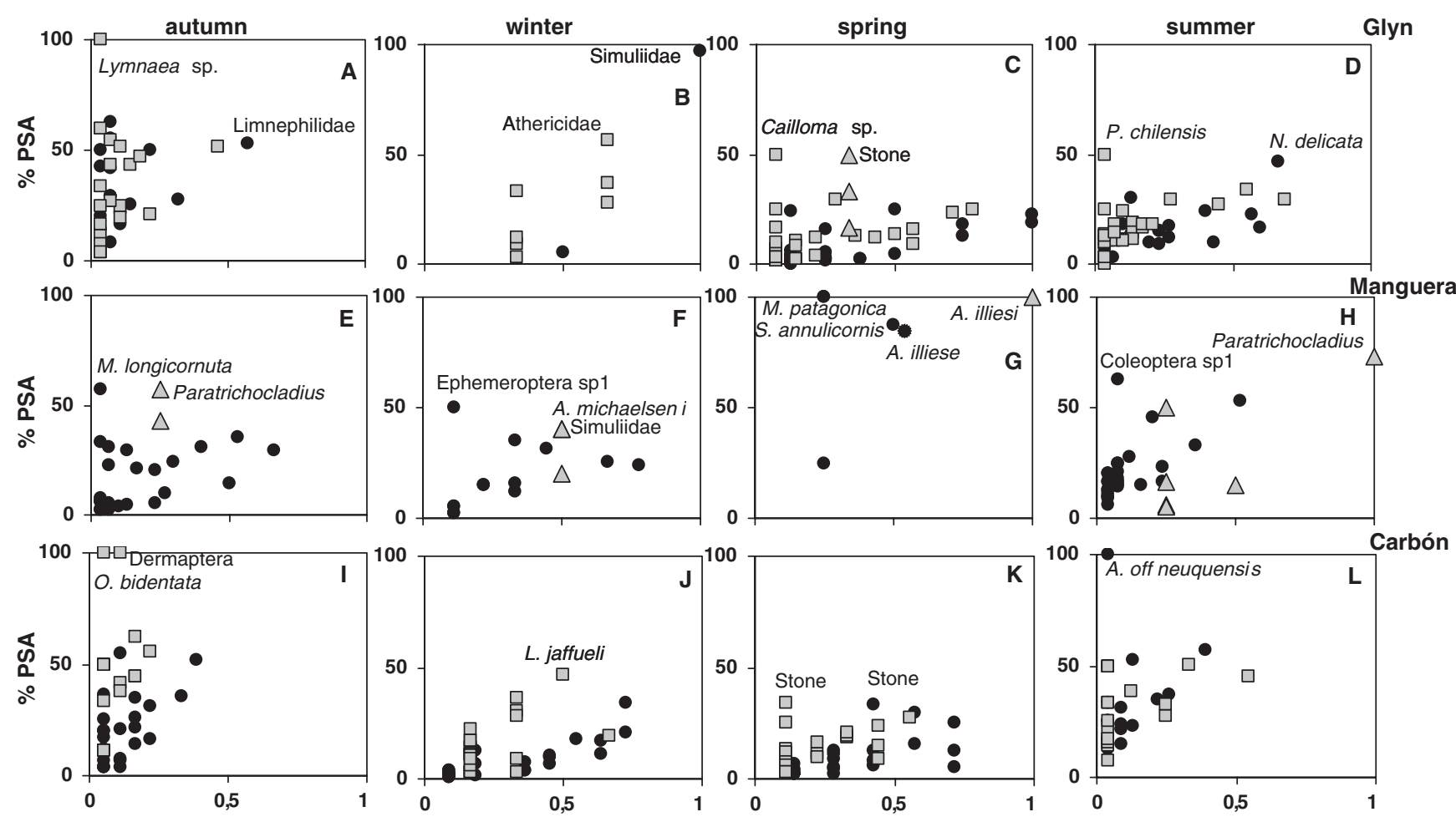

Fig. 3. Feeding strategy of $O$. mykiss, S. trutta and H. macraei through the year sampled in three Northwest Patagonian streams (Argentina). The most important prey categories are identified by shortened names. \% PSA: prey-specific abundance percentage. S. trutta $\square ; O$. mykiss $\bullet ; H$. macraei $\triangle$. 
diagonal from the origin to the upper right corner. There was, however, also a slight tendency toward an increased between-phenotype contribution to the niche width particularly in autumn (Glyn and Carbón) (Fig. 3(A, I)), in spring (Manguera for O. mykiss) (Fig. 3(G)) and in summer (Carbón) (Fig. 3(D)), as a few prey types were skewed toward the upper left of the diagram. This indicates that small fractions of individuals within the fish populations tended to specialize by predominantly feeding on a few specific prey.

\section{Discussion}

The streams considered in this study were dominated by the exotic $O$. mykiss in terms of both density and biomass, whereas the native $H$. macraei was scarcely represented in the samples, similar to findings by Di Prinzio et al. (2009). Hatcheria macraei is a rheophilic and negatively phototactic catfish (Menni, 2004) which inhabits fast flowing, clear, cold and well-oxygenated waters (Ringuelet 1975). This fish was widely distributed in Patagonia in the past, but is currently considered as rare (López et al., 2003). Their current restricted distribution could be related to a variety of causes like habitat loss, predation and competition from salmonids (Pascual et al., 2007).

According to the graphical method of Amundsen et al. (1996), the three fish species showed to be considered as generalist feeders. Overall, benthic invertebrates (Plecoptera, Trichoptera, Coleoptera and Diptera) were the main prey. These results are in line with those reported for these fish species at other localities of Patagonia (Ferriz, 1994; Arismendi et al., 2009; Barriga and Battini, 2009; Buria et al., 2009). The difference in the resource niche between exotic and native species is agreed with the competitive exclusion principle, which states that coexisting species should segregate in resource use. Under such circumstances, different feeding strategies may help to reduce interspecific competition. The higher diet overlaps were registered between $O$. mykiss and S. trutta at Glyn and Carbón, which suggests that there is a competitive coexistence of these species in spite of their extensive niche overlap. Extensive niche overlap has been suggested to occur between competitors that are similar in their skills to compete for resources (Ågren and Fagerstrøn, 1984; Keddy, 1989), such as when consumers differ in their foraging behavior toward the same renewable resource (Wilson et al., 1999). According to Ågren and Fagerstrøn (1984), competitors can survive by segregating along a resource gradient if they have ample differences in their ecological niches, but they can also coexist under conditions of extensive overlap if they are highly similar in their niche utilization, and thereby equal competitors (see also Keddy, 1989). It was observed that O. mykiss and H. macraei reflected significant diet overlap at Manguera in spring. It may be surprising that dissimilar species such as salmonids and a freshwater catfish have diets that are highly similar, as one should expect their distinct morphological differences to be reflected in segregated food niches. Hatcheria macraei is morphologically adapted for living at the bottom of the river and are regarded as strictly benthic fishes. The salmonids are, in contrast, morphologically adapted to adopt different positions in the water column and may feed on either benthic or drifting preys (Kalleberg, 1958). However, these two species, showed different niche width in spring, while $O$. mykiss reflected a broad niche width, H. macraei presented a narrow width wide with a specialization at population level. This is mainly related to the fact that both species changed their food preferences in spring and foraged almost exclusively on the Plecopteran A. illiesi (Fig. 3(G)). This pattern is similar to the one reported by Gabler and Amundsen (2010) for the Altantic salmon parr and the alpine bullhead in a sub-Arctic river and by Barriga and Battini (2009) who suggested that in order to reduce the predation risk or the inter-specific competition for food, H. macraei might partition the use of the feeding habitat in a Patagonian river. Accordingly, Penaluna et al. (2009) observed that three native fish species had niche overlap with the introduced $O$. mykiss and $S$. trutta, and that they changed their mesohabitat use after the reduction of salmonids abundance in two Patagonian rivers (Chile).

The levels of prey overlap observed between $O$. mykiss and S. trutta in Glyn and Carbón also changed markedly through the year and may be a reflection of temporal changes in food availability. However, some studies have indicated that when prey overlap between species is high, the resource competition is often low as a result of high abundance of their principal prey (Klemetsen, 1993; Høines and Bergstad, 2002; Barrera Oro, 2003). McIntosh et al. (1992) observed in New Zealand streams that native and exotic species temporally and spatially segregated the use of food resources and observed a small proportion of the fish populations specialising by predominantly feeding on a few specific prey. Hence, the wide population niche widths observed along the year were partly a result of mixed individual feeding strategies within the populations.

The magnitude of the impact of introduced salmonids on Patagonian native fish is difficult to determine due to the absence of pre-introduction information (Pascual et al., 2007). Similarly, Baigún and Ferriz (2003) indicated that it is not well understood how exotic fish have modified the structure of the communities in different Patagonian basins. Thus, the studies on food competition between native and exotic species might help to understand the co-adaptive process related to the salmonids' introduction.

Acknowledgements. This study was partially supported by CONICET (PIP5733), PADI FOUNDATION (Grant 19/2006). Special thanks to Drs M.L. Miserendino and M. Archangelsky, and Lic C. Brand for fieldtrip assistance. Thanks to anonymous reviewers for valuable comments that greatly improved the manuscript. This is the contribution to the Laboratorio de Investigaciones en Ecología y Sistemática Animal (LIESA) No. 76. 


\section{References}

Ågren G.I. and Fagerstrøn T., 1984. Limiting similarity in plants: randomness prevents exclusion of species with similar competitive abilities. Oikos, 43, 369-375.

Aigo J., Cussac V., Peris S., Ortubay S., Gómez S., López H., Gross M. and Battini J.B.M., 2008. Distribution of introduced and native fish in Patagonia (Argentina): patterns and changes in fish assemblages. Rev. Fish. Biol. Fisheries, 18, 387-408.

Amundsen P-A., 1995. Feeding strategy of Arctic charr: general opportunist, but individual specialist. Nord. J. Freshw. Res., $71,150-156$.

Amundsen P-A., Gabler H-M. and Staldvik F.J., 1996. A new approach to graphical analysis of feeding strategy from stomach contents data-modification of the Costello (1990) method. J. Fish. Biol., 48, 607-614.

Arismendi I., Soto D., Penaluna B., Jara C., Leal C. and LeónMuñóz J., 2009. Aquaculture, non-native salmonid invasions and associated declines of native fishes in Northern Patagonian Lakes. Fresh. Biol., 54, 1135-1147.

Baigún C. and Ferriz R.A., 2003. Distribution patterns of freshwater fishes in Patagonia (Argentina). Org. Div. Evol., $3,151-159$.

Barrera Oro E., 2003. Analysis of dietary overlap in Antarctic fish (Notothenioidei) from the South Shetland Islands: no evidence of food competition. Polar Biol., 26, 631-637.

Barriga J.P. and Battini M.A., 2009. Ecological significances of ontogenetic shifts in the stream-dwelling catfish, Hatcheria macraei (Siluriformes, Trichomycteridae), in a Patagonian river. Ecol. Freshw. Fish., 18, 395-405.

Barros S.E., Monaterio de Gonzo G. and Mosqueira M., 2001. Trophic ecology of fishes from a northwestern Argentinian mesoeutrophic river. Bol. Soc. Biol. Concep., 72, 7-23.

Bechara J.A., Moreau G. and Planas D., 1992. Top-down effects of brook trout (Salvelinus fontinalis) in a boreal forest stream. Can. J. Fish. Aquat. Sci., 49, 2093-2103.

Brönmark C., Dahl J. and Greenberg L., 1997. Complex trophic interactions in freshwater benthic food chains. In: Streit B. et al. (eds.), Evolutionary Ecology of Freshwater Animals, Birkhäuser, Berlin, 55-88.

Buria L., Albariño R., Díaz Villanueva V., Modenutti B. and Balseiro E., 2007. Impact of exotic rainbow trout on the benthic macroinvertebrate community from AndeanPatagonian headwater streams. Fund. Appl. Limnol. (Arch. Hydrobiol.), 168, 145-154.

Buria L.M., Albariño R.J., Modenutti B.E. and Balseiro E.G., 2009. Temporal variations in the diet of the exotic rainbow trout (Oncorhynchus mykiss) in an Andean-Patagonian canopied stream. Rev. Chil. Hist. Nat., 82, 3-15.

Casaux R. and Barrera-Oro E., 2002. Effects of a shore-based sampling programme on Notothenia coriiceps populations. Antartic Science, 14(3), 221-224.

Coronato F.R. and del Valle H.F., 1988. Caracterización hídrica de las cuencas hidrográficas de la provincia del Chubut, Publicación Técnica, Cenpat-Conicet, Puerto Madryn, Chubut, Argentina.

Dahl J. and Greenberg L., 1996. Impact on stream benthic prey by benthic vs. drift feeding predators: a meta-analysis. Oikos, 77, 177-182.
Di Prinzio C.Y. and Pascual M.A., 2008. The establishment of exotic Chinook salmon (Oncorhynchus tshawytscha) in Pacific rivers of Chubut, Patagonia, Argentina. Ann. Limnol. - Int. J. Lim., 44, 25-32.

Di Prinzio C.Y., Casaux R.J. and Miserendino M.L., 2009. Effects of land use on fish assemblages in Patagonian low order streams. Ann. Limnol. - Int. J. Lim., 45, 1-11.

Ferriz R.A., 1994. Diet of Olivaichthys viedmensis (Mac Donagh, 1931) and Hatcheria macraei (Girard, 1855) (Teleostei, Siluriformes) in the Limay River, Argentina. Nat. Patag. Cinc. Biol., 2, 83-88.

Gabler H.-M. and Amundsen P.-A., 2010. Feeding strategies, resource utilization and potential mechanisms for competitive coexistence of Atlantic salmon and alpine bullhead in a sub-Artic river. Aquat. Ecol., 44, 325-336.

Høines A.S. and Bergstad O.A., 2002. Food partitioning by flatfishes on a herring spawning ground. Sarsia, 87, 19-34.

Kalleberg H., 1958. Observations in a stream tank of territoriality and competition in juvenile salmon and trout (Salmo salar L. and Salmo trutta L.). Rep. Inst. Freshw. Res. Drott., 39, 55-98.

Keddy P.A., 1989. Competition, Chapman and Hall, New York.

Klemetsen A., 1993. The food of the long-rough dab (Hippoglossoides platessoides limnandoides Bloch) in Balsfjorden, north Norway. Sarsia, 78, 17-24.

Kolar C.S. and Lodge D.M., 2000. Freshwater nonindigenous species: Interactions with other global changes. In: Moonley, H.A. and Hobbs, R.J. (eds.), Invasive Species in a Changing World, Island Press, Washington, DC, pp. 3-30.

Krebs C.J., 1989. Ecological Methodology, Harper Collins Publishers, New York.

Lattuca M.E., Ortubay S., Battini M.A., Barriga J.P. and Cussac V.E., 2007. Presumptive environmental effects on body shape of Aplochiton zebra (Pisces, Galaxiidae) in northern Patagonian lakes. J. Appl. Ichthyol., 23, 25-33.

Levins R., 1968. Evolution in Changing Environments: Some Theoretical Explorations, Princeton University Press, Princeton, NJ.

López H.L., Miquelarena A.M. and Menni R.C., 2003. Lista comentada de los peces continentals de la Argentina, ProBiotA, Serie Técnica y Didáctica No. 5, La Plata, Buenos Aires, Argentina.

McDowall R.M., 2003. Impact of introduced salmonids on native galaxiids in New Zealand upland stream: a new look at an old problem. Trans. Am. Fish. Soc., 132, 229-238.

McIntoch A.R., Townsend C.R. and Crowl T.A., 1992. Competition for space between introduced brown trout (Salmo trutta L.) and a native galaxiid (Galaxias vulgaris Stokell) in a New Zealand stream. J. Fish. Biol., 41, 63-81.

Menni, 2004. Peces y ambientes en la Argentina continental, Monografías del Museo Argentino de Ciencias Naturale, Buenos Aires.

Molineri C., 2008. Impact of rainbow trout on aquatic invertebrate communities in subtropical mountain streams of northwest Argentina. Ecol. Aust., 18, 101-117.

Odum E., 1971. Fundamentals of Ecology, Saunders, Philadelphia.

Pascual M.A. and Ciancio J.E., 2007. Introduced anadromous salmonids in Patagonia: Risks, uses, and a conservation paradox. In: Bert T.M. (ed.), Ecological and Genetic Implications of Aquaculture Activities, Springer, New York, USA, Chapter 18, 333-353. 
Pascual M.A., Cussac V., Dyer B., Soto D., Vigliano P., Ortubay S. and Macchi P., 2007. Freshwater fishes of Patagonia in the 21 st Century after a hundred years of human settlement, species introductions, and environmental change. A.H.M., 10, 212-227.

Peckarsky B.L., 1982. Aquatic insect predator-prey relations. Bioscience, 32, 261-266.

Penaluna B., Arimsendi I. and Soto D., 2009. Evidence of interactive segregation between introduced trout and native fishes in Northern Patagonian Rivers, Chile. Trans. Am. Fish. Soc., 138, 839-845.

Ringuelet R., 1975. Zoogeografía y ecología de los peces de aguas continentales de la Argentina y consideraciones sobre las áreas ictiológicas de América del Sur. Ecosur, 2, $1-122$.

Roughgarden J., 1972. Evolution of niche width. Am. Nat., 106, 683-718.
Sokal R.R. and Rohlf F.J., 1995. Biometry (3rd edn), W.H. Freemand and Company, New York.

Soto D., Arismendi I., Di Prinzio C.Y. and Jara F., 2007. Establishment of Chinook salmon (Oncorhynchus tshawytscha) in Pacific basins of southern South America and its potential ecosystem implications. Rev. Chil. Hist. Nat., 80, 81-98.

Townsend C.R., 2003. Individual, population, community and ecosystem consequences of a fish invader in New Zealand streams. Conserv. Biol., 17, 38-47.

Vitousek P.M., 1990. Biological invasions and ecosystem process towards an integration of biology and ecosystem studies. Oikos, 57, 7-13.

Wallace R.K., 1981. An assessment of diet-overlap indexes. Trans. Am. Fish. Soc., 110, 72-76.

Wilson W.G., Osenberg C.W., Schmitt R.J. and Nisbet R.M., 1999. Complementary foraging behaviours allow coexistence of two consumers. Ecology, 80, 2358-2372. 